\title{
POLICE REFORM IN VIOLENT DEMOCRACIES IN LATIN AMERICA ${ }^{+}$
}

\author{
Mariana Mota Prado* \\ Michael Trebilcock** \\ Patrick Hartford ${ }^{* * *}$
}

August 16, 2012

\footnotetext{
${ }^{+}$We would like to thank for helpful comments and suggestions participants in the Faculty Workshop at the University of Toronto Faculty of Law (February 13, 2012), the Law and Economic Development Conference (University of Chicago Law School, April 20-21, 2012) and the SELA Conference (Seminar in Latin America on Constitutional and Political Theory, Mexico City, June 8-10, 2012). Special thanks to Daniel Brinks, Eduardo Estevez and Linn Hammergren for detailed comments on earlier drafts. The usual disclaimers apply.

${ }^{*}$ Associate Professor, Faculty of Law University of Toronto

${ }^{* *}$ University Professor and Chair in Law and Economics, University of Toronto

*** JD/MGA Candidate, University of Toronto
} 


\section{Table of Contents}

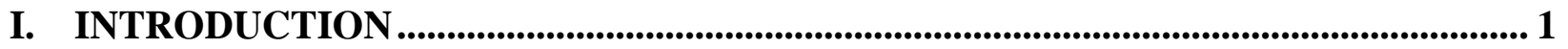

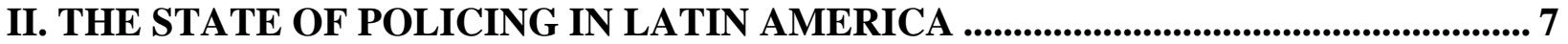

a. The Aspiration: Democratic Policing …............................................................... 7

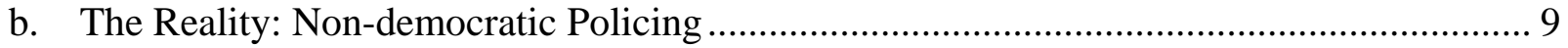

c. The Problem: Types of Deviations from the Democratic Criteria.................................... 12

III. POLICE REFORM IN LATIN AMERICA ................................................................ 15

a. Independence: Dealing with the Principal-Agent Problem ............................................ 17

b. Accountability: Chosing the Right Sequence ............................................................... 21

c. Bypassing Dysfunctional Institutions ….................................................................. 28

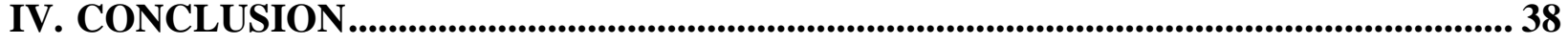




\section{INTRODUCTION}

Violence has become an increasingly serious problem in many developing countries. According to a recent (2011) World Bank World Development Report, entitled Conflict and Development: Overcoming Conflict and Fragility, security is a "primary development challenge of our time.” ${ }^{1}$ In addition to traditional forms of urban violence, new threats have emerged such as organized crime and trafficking, civil unrest due to global economic shocks, and terrorism. ${ }^{2}$

One and a half billion people live in areas affected by fragility, conflict, or organized criminal violence.

Within developing countries, Latin America faces particularly acute problems with violence: while homicide rates have been decreasing in most of the world, Latin American and Caribbean countries are the exception, possibly only accompanied by parts of sub-Saharan Africa. $^{3}$ Indeed, after experiencing a steep rise in crime rates in the 1990s, Latin America is currently one of the most violent regions in the world. ${ }^{4}$ While data is not available for some African countries, the Latin American/Central American/Caribbean region (LAC) has the highest homicide rates per 100,000 of population per region per year. According to the UNODC 2011

World Homicide Report, eight of the ten countries with the highest reported homicide rates in the world are located in this region: ${ }^{5}$

\footnotetext{
${ }^{1}$ The World Bank, “Conflict, Security, and Development,” World Development Report 2011 (Washington: The World Bank, 2011), 1.

2 Ibid, 3.

3 Ibid, 9.

${ }^{4}$ Rodrigo Soares and Joana Naritomi, "Understanding High Crime Rates in Latin America: The Role of Social and Policy Factors,” in The Economics of Crime: Lessons For and From Latin America, ed. Rafael Di Tella (Chicago: University of Chicago Press, 2010); Julio Jacobo Waiselfisz, Mapa da Violencia: Os jovens da America Latina (Rede de Informação Tecnológica Latino-Americana (RITLA) and Ministério da Educação, 2008).

${ }^{5}$ United Nations Office on Drug and Crime. “UNODC Homicide Statistics,” United Nations Office on Drugs and Crime, accessed January 17, 2012, http://www.unodc.org/unodc/en/data-and-analysis/homicide.html. See Appendix A for a complete list of homicide rates in Latin America.
} 


\begin{tabular}{|r|l|c|l|}
\hline 1 & Honduras & 82.1 & LAC \\
\hline 2 & El Salvador & 66 & LAC \\
\hline 3 & Cote d'Ivoire & 56.9 & Africa \\
\hline 4 & Jamaica & 52.1 & LAC \\
\hline 5 & Venezuela (Bolivarian Republic of) & 49 & LAC \\
\hline 6 & Belize & 41.7 & LAC \\
\hline 7 & Guatemala & 41.4 & LAC \\
\hline 8 & US Virgin Islands & 39.2 & LAC \\
\hline 9 & Saint Kitts and Nevis & 38.2 & LAC \\
\hline 10 & Zambia & 38 & Africa \\
\hline
\end{tabular}

By way of comparison to homicide rates in developed countries, in 2011 the rate in the US was 5.0, Belgium 1.7, Canada, 1.8, New Zealand 1.5, the UK (England and Wales) 1.2, and Australia 1.2. ${ }^{6}$ Even in comparison to many other developing countries, the homicide rates in Latin America are striking. For example, the homicide rate in India is 3.4, Bangladesh 2.7, South Korea 2.9, China 1.1, and Singapore 0.5. While other crime rates are also high (e.g., robbery, breaking and entering, rape, assault), massive under-reporting problems and variable data collection methods render data for these crimes much less reliable and comparable than for homicide statistics (although these are not entirely free from reliability issues). Law and order problems are consistently ranked as the leading concern of many Latin Americans in public opinion surveys. ${ }^{7}$

In addition to human losses and intangible injuries (such as psychological trauma), violence causes significant economic losses associated with "healthcare costs, other institutional costs, private insurance costs, and material losses.” ${ }^{8}$ As a proportion of GDP, these costs are

\footnotetext{
${ }^{6}$ Ibid.

${ }^{7}$ Mark Ungar, “Latin America’s Police: Advancing Citizen Security?”, (paper presented at the Violence and Citizenship in Post-Authoritarian Latin America Conference, Princeton, New Jersey, March 7, 2008 ), 2.

${ }^{8}$ Roberto Briceño-León, Andrés Villaveces, and Alberto Concha-Eastman, "Understanding the uneven distribution of the incidence of homicide in Latin America,” International Journal of Epidemiology 37, (2008): 755.
} 
estimated at 3.6\% for Mexico, $6.4 \%$ for Colombia, and 6.7\% for Guatemala. ${ }^{9}$ The negative effect of high homicide rates on life expectancy is also thought to reduce planning horizons and detract from optimal levels of saving and investment. ${ }^{10}$

These trends stand in striking contrast to the optimism engendered by the wave of democratization that has rolled through Latin America in the last three decades. In 1977, in Latin America itself, only Colombia, Costa Rica and Venezuela were democracies. Since that time, the Dominican Republic, Peru, Ecuador, Honduras, Bolivia, Argentina, El Salvador, Uruguay, Brazil, Guatemala, Chile, Paraguay, Haiti, Nicaragua, Panama, and Mexico have all moved to (at least nominally) democratic political regimes, superseding previous military or autocratic political regimes, or in some cases (such as Guatemala) as the culmination of extended civil wars. ${ }^{11}$ The optimism engendered by this wave of democratization was in part predicated on assumptions that democratic political regimes were likely to address more effectively some of the underlying sources of inequality and grievances in countries in the region, as well as heralding the end of the deployment of violent forms of repression by military or autocratic governments. $^{12}$

It was also assumed that police forces that had often been conscripted or enlisted in aid of the maintenance of military or autocratic governments and were often a major agent of repression, violence and human rights abuses, would, in the new democratic era, rapidly be transformed into more conventional civil police forces, charged with maintaining law and order

\footnotetext{
${ }^{9}$ Ibid.

${ }^{10}$ Soares and Naritomi, "Understanding High Crime Rates in Latin America," 20.

${ }^{11}$ Michael Reid, Forgotten Continent: The Battle for Latin America's Soul (New Haven: Yale University Press, 2007), 120-121.

${ }^{12}$ Enrique Desmond Arias and Daniel Goldstein, ed. Violent Democracies in Latin America (Durham: Duke University Press, 2010), 2; Paulo Sergio Pinheiro, "Governo Democrático, violência e Estado (ou não) de direito", in Brasil: fardo do passado, promessa do future, ed. Leslie Bethell (Rio de Janeiro: Civilização Brasileira, 2002), 237270; Paulo Sergio Pinheiro, "The Paradox of Democracy in Brazil", The Brown Journal of World Affairs 7, no. 2 (2002): 113-122.
} 
and serving and protecting the legitimate security interests of citizens, while respecting their basic civil and political rights. ${ }^{13}$ Most of these assumptions have proven unfounded in many (but not all) countries in Latin America, where police abuse and violence have in many cases actually been rising since the emergence of democratic political regimes. ${ }^{14}$

In this paper, we seek to explore the challenges to effective policing in what have been characterized in many cases as "violent Latin American democracies.”15 This expression captures the idea that conventional typologies of political regimes do not seem to capture the problems associated with state and interpersonal violence that characterizes many Latin American democracies today. The most extreme argument is that "if one considers violence as a measure of democratic failure - with greater levels of violence indicating a breakdown of democratic institutions and values - then Latin American democracies could be considered profoundly undemocratic.”16 A less extreme version of this argument claims that such high levels of violence and insecurity contradict a democratic ideal of peace and these countries should therefore be described as imperfect or incomplete democracies. ${ }^{17}$ Despite their differences, both versions of this argument share one thing in common: they assume that there is something deficient with democratic regimes with such high levels of violence and, therefore, Latin America has not yet completed its democratic transition.

\footnotetext{
${ }^{13}$ Anthony Pereira and Mark Ungar, "The Persistence of Mano Dura: Authoritarian Legacies and Policing in Brazil and the Southern Cone," in Authoritarian Legacies and Democracy in Latin America and Southern Europe, ed. Hite and Cesarini. (Notre Dame: University of Notre Dame Press, 2004), 263.

${ }^{14}$ Pereira and Ungar, "The Persistence of Mano Dura: Authoritarian Legacies and Policing in Brazil and the Southern Cone,"1; Arias and Goldstein, Violent Democracies in Latin America, 263-266. It is important to note, however, that some of the most violent countries are the ones that are longstanding democracies (e.g., Colombia \& Jamaica).

${ }^{15}$ Enrique Arias and Daniel Goldstein, Violent Democracies in Latin America.

${ }^{16}$ Ibid, 2.

${ }^{17}$ John Bailey and Roy Godson, Organized Crime \& Democratic Governability: Mexico and the U.S.-Mexican Borderlands (Pittsburgh University Press, 2000); Otwin Marenin, "Changing police, policing change: some thematic questions," in Changing police, policing change: International Perspectives, ed. Otwin Marenin (New York: Garland Publishing, 1996); John Gledhill, Power and Its Disguises: Anthropological Perspectives on Politics (London: Pluto Press, 2000).
} 
In addition to being important for democracy, effective policing should be an essential part of rule of law reforms. We share with other commentators ${ }^{18}$ the view that both domestic and international proponents of rule of law reform in developing countries face an underacknowledged challenge of rendering rule of law reform politically salient to most citizens of these countries in their daily lives. Very few citizens, over the course of their lifetimes, are likely to have any involvement in the formal court system, but many, on a daily basis, will face law and order issues where the policing function is of critical importance to them. In sum, police reform should be viewed as an essential part of the rule of law agenda in any country. Moreover, rule of law seems particularly important in democratic transitions in Latin America (and elsewhere). According to O’Donnell, “[t]he rule of law is among the essential pillars upon which any high-quality democracy rests”. ${ }^{19}$ In the absence of the rule of law, which guarantees full and equal legal protection to all, formally democratic states (i.e., those with regular elections and formal structures of democratic governance) lack many qualities that guarantee not only political, but also many other forms of social and economic engagement. ${ }^{20}$

The central question of this paper is what kind of reforms are necessary to guarantee that Latin American police forces meet what Bayley calls "the democratic criteria”: 1) police are accountable to law, not to government; 2) police protect human rights, including those related to democratic participation; 3) there are constraints on the use of police force that are enforced by

\footnotetext{
${ }^{18}$ For examples of commentators who share our view, see Thomas Carothers, "The Rule of Law Revival," Foreign Affairs 7 (1998): 95; Stephen Golub, “A House without Foundation,” in Promoting the Rule of Law Abroad: In Search of Knowledge, ed. Thomas Carothers (Washington, DC: Carnegie Endowment for International Peace, 2006); Bryant Garth, "Building Strong and Independent Judiciaries for the New Law and Development: Beyond the Paradox of Consensus Programs and Perpetually Disappointing Results,” DePaul Law Review 52 (2002): 383; Michael Trebilcock and Ronald Daniels, Rule of Law Reform and Development: Charting the Fragile Path of Progress (Cheltenham: Edward Elgar, 2008), 355; Brian Tamanaha, On the Rule of Law: History, Politics, Theory (Cambridge: Cambridge University Press, 2004).

${ }^{19}$ Guillermo O’Donnell, “Why the Rule of Law Matters,” Journal of Democracy 15, no. 4 (2004): 42.

${ }^{20}$ Teresa Caldeira and James Holston, "Democracy and Violence in Brazil," Comparative Studies in Society and History 41, no. 4 (1999).
} 
institutions external to the police force; 4) the police force's priority is the protection of citizens as individuals and private groups, not the state. ${ }^{21}$

We acknowledge that in any discussion of police reform it is difficult to avoid broader issues relating to effective policing methods. Police reform is intrinsically linked with a concern with reducing crime rates. However, police effectiveness in fighting crime engages a much larger and more complex legal, political, social and economic matrix and its success depends in part on the nature of the interactions between reforms to the police and other elements in the matrix. The complexity of this topic and its multifaceted approach does not allow us to deal with it in this short paper. The primary focus of this paper is to discuss the types of reforms that ensure that a police force is abiding by the most fundamental principles of the rule of law under a democratic regime. We recognize that in some cases the two problems are so entangled that it is not possible to discuss police reform without addressing effective ways to reduce crime. However, as we argue in the paper, this is not always the case. In many countries it seems possible to separate the two.

The restricted focus of our analysis (reforms that ensure that a police force operates according to basic principles of the rule of law in a democratic society) does not imply that one should ignore the complex institutional interdependencies ${ }^{22}$ between the police force and other institutions that operate in Latin American democracies. For example, meeting Bayley’s democratic criteria depends on an effective prosecutorial function and effective disposition of cases by the judicial system, and effective correctional institutions and policies. Yet given the significant obstacles to across-the-board reforms of their entire set of legal institutions

\footnotetext{
${ }^{21}$ David H. Bayley, Changing the Guard: Developing Democratic Police Abroad (New York: Oxford University Press, 2006).

${ }_{22}^{22}$ Mariana Mota Prado and Michael Trebilcock, "Path Dependence, Development, and the Dynamics of Institutional Reform,” University of Toronto Law Journal 59 (2009).
} 
simultaneously, we believe that there is merit in isolating policing, a function that affects the daily lives of citizens, for more detailed analysis.

The paper will be structured as follows: Part II will present the "democratic criteria” for police forces and assess if and how actual policing in Latin America deviates from these "democratic criteria”, offering a typology of the different types of deviation. Based on the typology presented in Part II and an analysis of successful and failed reforms, Part III will discuss what kinds of reform strategies could be successful in different countries in the region. The paper concludes with some lessons that may be useful to Latin American and other middleincome developing countries.

\section{THE STATE OF POLICING IN LATIN AMERICA}

\section{a. The Aspiration: Democratic Policing}

The idea that the police should play a crucial role in protecting human rights and assuring equal treatment of citizens was endorsed in 1979 by the United Nations Code of Conduct for Law Enforcement and has been acknowledge in prior academic writings. ${ }^{23}$ This ideal police force has been labeled "democratic policing" and its essential characteristic is the fact that it is accountable to law rather than to government. ${ }^{24}$

Democratic policing is especially relevant for countries in transition. In many developing countries, a politicized police force has historically acted against citizens, whether as a tool of the Communist Party, an authoritarian government, or a colonizing government. In these cases, the police were alienated from citizens because of their exclusive focus on securing social order

\footnotetext{
${ }^{23}$ Trebilcock and Daniels, Rule of Law Reform and Development, 110; H. Goldstein, Policing a Free Society (Cambridge: MAL Ballinger, 1977); Peter K. Manning, “The Study of Policing,” Police Quarterly 8, no. 1 (2005): 23.

${ }^{24}$ Bayley, Changing the Guard, 19-22.
} 
and defending ruling interests. ${ }^{25}$ In Latin America, this legacy has produced a misconception of the role of the police that "blinds them to the simple perception that the police are citizens, as are those with whom they work, and that there is no enemy."26 In this context, democratic policing can impact positively on the transition to democracy directly or indirectly. Directly, "it would be contradictory to say that a country was democratic if its police arbitrarily arrested people, used unreasonable force, and suppressed political dissent."27 Indirectly, police can secure the processes that are essential to democratic life, such as voting, speaking, and assembling. ${ }^{28}$ As a consequence, democratic policing is a necessary (but not sufficient) step in the transition to a democratic regime. $^{29}$

While democratic policing is essential for the existence of a democratic regime, the term democratic policing is not reserved for or circumscribed to democratic countries. Democratic policing is easier to achieve in a political democracy, ${ }^{30}$ but is also a valuable model to follow even in non-democratic countries. Increasing transparency and accountability can limit the most egregious human rights violations and espouse benchmarks to which the reform process can aspire. $^{31}$ Thus, discussions of democratic policing (and reforms to implement it) do not presuppose or require a fully functional democratic regime.

A potential argument against democratic policing is the popular perception in Latin America - even among police officers - that the police are more effective in ensuring public

\footnotetext{
${ }^{25}$ Attannibi E.O. Alemika, "Police Policing and Rule of Law in Transitional Countries," in Human Rights and the Police in Transitional Countries, ed. Lone Lindholt et al. (The Hague: Kluwer Law International, 2003), 74.

${ }^{26}$ Paul Chevigny, "Defining the Role of the Police in Latin America," in The (Un)Rule of Law and the Underpriviliged in Latin America, ed. Juan E. Mendez et al. (Notre Dame: University of Notre Dame Press, 1999), 49.

${ }^{27}$ Bayley, Changing the Guard, 18.

${ }^{28}$ Ibid.

${ }^{29}$ Ibid.

${ }^{30}$ David Bayley, Democratizing the Police Abroad: What to Do and How to Do It (Washington: US Department of Justice, 2001), 13.

${ }^{31}$ Trebilcock and Daniels, Rule of Law Reform and Development, 110.
} 
safety by violating human rights and infringing the rule of law (so called mano dura). ${ }^{32}$ The counter-arguments against this perception are manifold. First, empirical evidence suggests that violating the rule of law contributes only marginally to deterrence. ${ }^{33}$ Second, these violations are likely to make the job of the police harder, as it alienates the public and reduces citizen’s willingness to cooperate with the police. ${ }^{34}$ Third, these violations may further undermine rule of law institutions, as lawless behavior constitutes a missed opportunity for rule of law institutions to mature and develop. ${ }^{35}$ Finally, there is no guarantee that the abuses that victimize criminals will not also be used against innocent citizens. As Paul Chevigny states, a "society cannot obtain 'security’ through police lawlessness, precisely because it is lawless.”36

\section{b. The Reality: Non-democratic Policing}

Latin America is a region that defies broad generalizations, as the differences and peculiarities among its fifty ${ }^{37}$ countries are numerous. Policing is not an exception. $^{38}$ Nevertheless, policing in Latin American countries suffers from many serious and relatively common problems. In many countries, police forces are militarized and hierarchical, reflecting the practices of former authoritarian regimes and focusing on responsive rather than preventive

\footnotetext{
${ }^{32}$ David Bayley, "Law Enforcement and the Rule of Law: Is there a Tradeoff?”, Criminology \& Public Policy 2, no. 1 (2002): 136.

33 Ibid., 138; Niels Uildriks, "Policing Insecurity and Police Reform in Mexico City,” in Policing Insecurity, ed. Niels Uildriks (Lanham: Lexington Books, 2009).

${ }^{34}$ Bayley, "Law Enforcement and the Rule of Law: Is there a Tradeoff?”, 138; Uildriks, "Policing Insecurity and Police Reform in Mexico City."

${ }^{35}$ Paul Chevigny, "Defining the Role of the Police in Latin America," 111.

${ }^{36}$ Ibid.

${ }^{37}$ By Latin America, we are referring to what the United Nations Statistical Division calls the Latin American and Caribbean region, which includes the Caribbean, Central America, and South America. For a complete list, please see United Nations Statistical Division, "Composition of macro geographical (continental) regions, geographical sub-regions, and selected economic and other groupings," United Nations Statistical Division, last modified September 20, 2011, http://unstats.un.org/unsd/methods/m49/m49regin.htm.

38 Jose Miguel Cruz, "Police Abuse in Latin America", AmericasBarometer Insights 11, (2009). Available at www.americasbarometer.org, showing that in 2008 the percentage of people who reported having suffered some for of abuse by the police in the last twelve months was above 7\% in Argentina, Bolivia, Colombia and El Salvador, whereas it was around or below 3\% in Venezuela, Costa Rica, Honduras, Paraguay and Panama. The number and scope of police reforms also varies significantly from country to country, as we will discuss below.
} 
measures. ${ }^{39}$ Corruption is endemic and often facilitates the relationship between police and powerful drug cartels, undermining attempts at reforming the police and other complementary institutions. ${ }^{40}$ Police abuse and extra-judicial killings are common. ${ }^{41}$ Finally, many police agencies lack essential human and material resources. ${ }^{42}$

Faced with extremely high crime rates and ineffective public police forces, wealthier Latin American citizens have been increasingly relying on private security services, including hiring bodyguards, moving to gated communities, and even buying bullet-proof cars. While the ratio between private security guards and police officers in developed countries runs generally at 2 to 1 , in some Latin American countries the ratio has increased to 11 to 1 . Many private security forces are unregistered and operate in the informal sector without effective state oversight (and are often partly staffed by moonlighting police officers). One consequence of this trend is that it creates a major political economy problem in that wealthier citizens are reluctant to underwrite, through their taxes, improvements in public police forces, given that they have, in many cases, effectively exited from public police protection. ${ }^{43}$ This leaves poor people increasingly left to police themselves, which has in some countries led to an increase in self-help

\footnotetext{
${ }^{39}$ Pereira and Ungar, “The Persistence of Mano Dura”, 268-269.

${ }^{40}$ Diane Davis, "Undermining the Rule of Law: Democratization and the Dark Side of Police Reform in Mexico," Latin American Politics and Society 48, no. 1 (2008): 67.

${ }^{41}$ Mark Ungar, “Latin America’s Police: Advancing Citizen Security?”; Ruth Stanley, “Living in a Jungle: State Violence and Perceptions of Democracy in Buenos Aires," in Violent Democracies in Latin America, ed. Enrique Desmond Arias and Daniel M. Goldstein (Durham: Duke University Press, 2010); Anthony Pereira, "Public Security, Private Interests, and Police Reform in Brazil," in Democratic Brazil Revisited, ed. Peter Kingstone and Timothy Power (Pittsburgh: University of Pittsburgh Press, 2008); Daniel Brinks, "Informal Institutions and the Rule of Law: The Judicial Response to State Killings in Buenos Aires and Sao Paulo in the 1990s,” Comparative Politics 36, no. 1 (2003): 6-7.

${ }^{42}$ Theodore Leggett, Crime and Development in Central America: Caught in the Crossfire, United Nations Office on Drugs and Crime, 2007, 31. Indicating that in countries like Honduras and Guatemala, the problem is a low ratio of police to public; Soares and Naritomi. "Understanding High Crime Rates in Latin America"; David A. Shirk and Alejandra Rios Cázares, "Introduction: Reforming the Administration of Justice in Mexico," in Reforming the Administration of Justice in Mexico, ed. Wayne A. Cornelius and David A. Shirk (Notre Dame: University of Notre Dame Press, 2007), 20.

${ }^{43}$ See Albert Hirschman, Exit, Voice and Loyalty: Responses to Decline in Firms, Organizations, and States (Cambridge, Mass.: Harvard University Press, 1970).
} 
forms of protection, including delegation of security to drug gangs, vigilantism, and community lynchings. $^{44}$

With such a long list of problems, it is apparent that Latin America fails to meet the democratic policing criteria. ${ }^{45}$ With rampant corruption in many countries that goes unpunished, many police agencies are accountable to neither government nor the law. Instead, in countries like Peru, Mexico, Guatemala, Brazil, and Jamaica (by no means an exhaustive list) the police are bought off by drug gangs on a regular basis. ${ }^{46}$ This is coupled with the fact that there is a dire lack of external accountability. In the countries where there is civilian oversight over the police, regulators and ombudsmen lack effective authority to hold the agency to account. ${ }^{47}$ Those holding these positions are frequently placed there as a result of political patronage. With few exceptions, investigations into officer misconduct are conducted internally and rarely result in serious punishment. ${ }^{48}$

It is noteworthy that there are some important exceptions to regional trends. While Chile's Carabineros are hierarchical and militarized, the police force is renowned for its lack of corruption. ${ }^{49}$ Costa Rica is another country with a functional police force with a record for

\footnotetext{
${ }^{44}$ See Jennifer L. Johnson, "When the Poor Police Themselves: Public Insecurity and Extralegal Criminal-Justice Administration in Mexico," Legitimacy and Criminal Justice: International Perspectives, ed. Tom Tyler (New York: Russell Sage Foundation, 2007); see more generally, Mariana Mota Prado, A Tragedy of the Privates: Private Security Services in Latin America, Paper prepared for the SELA Conference, June 2010, Santiago, Chile. Available at http://www.law.yale.edu/documents/pdf/sela/MatoPrado_Eng_CV_20100420.pdf.

${ }^{45}$ Mercedes S. Hinton, “A distant reality: democratic policing in Argentina and Brazil,” Criminal Justice 5, no. 1 (2005): 95.

${ }^{46}$ George Henry Millard, "Drugs and Corruption in Latin America,” Dickinson Journal of International Law 15 (1996):534-535; BBC News, "Humala sacks Peru police commanders in corruption purge,” BBC News, October 11, 2011, accessed November 23, 2011, http://www.bbc.co.uk/news/world-latin-america-15250508; Leggett, "Crime and Development in Central America," 17-18; John P. Sullivan and Robert J. Bunker, "Drug Cartels, Street Gangs, and Warlords," Small Wars \& Insurgencies 13, no. 2 (2002): 45-47; Davis, "Undermining the Rule of Law," 73.

${ }^{47}$ Pereira, "Public Security, Private Interests, and Police Reform in Brazil."

${ }^{48}$ Sandro Cabral, Sergio Lazzarini, and Allan Claudius Barbosa, "Monitorando a Polícia: Um Estudo sobre a Eficácia dos Processos Administrativos Envolvendo Policiais Civis na Corregedoria Geral da Bahia,” Organizações \& Sociedade 15 no. 47 (2008).

${ }^{49}$ Lucia Dammert. "Police and Judicial Reform in Chile," in Policing Insecurity: Police Reform, Security, and Human Rights in Latin America, ed. Niels A. Uildriks (Lanham: Lexington Books, 2009), 152.
} 
respecting human rights. ${ }^{50}$ Both these countries have relatively lower levels of police abuse than other countries in the region. ${ }^{51}$ Despite these notable successes, however, it remains clear that there is still a widespread failure of policing to meet democratic criteria across the region.

\section{c. The Problem: Types of Deviations from the Democratic Criteria}

Policing in Latin America is so rife with problems that it requires some reframing of the democratic criteria for us to effectively assess the nature of the problem. As currently formulated, the democratic criteria presuppose a spectrum between authoritarian and democratic policing. The requirement that police be accountable to law, not government, implicitly assumes that the police are accountable to one of the two. However, in many Latin Americas countries the police have become less authoritarian without becoming more democratic. In countries like Mexico, for instance, the police are accountable to drug traffickers. In other countries, like Argentina, the government is simply unable to control the police, who operate by their own rules. Consequently, an autocratic police force is only one of many different ways that police agencies can deviate from the democratic criteria.

In an attempt to facilitate the diagnosis of different problems and outline potential policy proposals to solve these problems, we will use ideal types. ${ }^{52}$ These ideal types will indicate different types of deviation from these democratic criteria and are three fold. The first type is the autocratic police force, which plays a large role in the concern with police reform in countries that are transitioning from military or autocratic rule to democratic rule, as many Latin American

\footnotetext{
${ }^{50}$ Q.A.M. Eijkman, "We are Here to Serve You! Public Security, Police Reform and Human Rights Implementation in Costa Rica” (PhD diss., Utrecht University, 2007), 2.

${ }^{51}$ Cruz, "Police Abuse in Latin America." Indicating that as a percentage of population reporting police abuse in the last twelve months, Costa Rica had 3.6\% and Chile 4\%. For a comparison, see Note 38 above.

${ }^{52}$ A similar conceptual exercise was used to discuss policing in the Post-Soviet Union, which is described as having predatory policing. See Theodore Gerber and Sarah Mendelson, "Public Experience of Police Violence and Corruption in Contemporary Russia: A Case of Predatory Policing?” Law \& Society Review 42, no. 1 (2008).
} 
countries were in the late 1970s and 1980s. ${ }^{53}$ The autocratic police is controlled by and protective of the interests of a repressive regime.

There are at least two other types of deviation from the democratic criteria that seem to be present in Latin America, but do not seem to be captured by the concept of autocratic police. There are countries in which the police forces seem to have moved away from the autocratic police form, but instead of becoming democratic, they have become controlled by drug gangs. We call this type the criminal police. Alternatively some police forces become unaccountable and uncontrollable institutions that set their own policies and execute them independently of the state. We call this type the autarkic police.

Despite exhibiting important differences, the three deviations from the democratic police outlined above (autocratic, criminal and autarkic) have one thing in common: they are not accountable to the law. They also lack other characteristics of the democratic police force, such as respect for human rights, protection of civil and political rights, accountability to people outside the organization, and servicing the needs of citizens.

We propose here that all the characteristics of each ideal-type of police force are directly derived from a principal-agent relationship. For example, the criminal police violate human rights for criminal motives (i.e. to protect the interests of criminals who pay the police for protection), whereas the autarkic police violate human rights for ideological motives (they truly believe that mano dura is the best crime-fighting strategy). In these cases, the principals are, respectively, criminal groups and the police itself. In the case of the democratic police, in turn,

\footnotetext{
${ }^{53}$ Nathan W Pino and Michael D. Wiatrowski, “Assessing the Obstacles," in Democratic policing in transitional and developing countries, ed. Nathan Pino and Michael D. Wiatrowski (Aldershot: Ashgate Publishing Limited, 2006), 31; Hugo Fruhling. "Recent Police Reform in Latin America" in Policing Insecurity, ed. Niels Uildriks (Lanham: Lexington Books, 2009), 23.
} 
the principals are the citizens of the democratic polity, and their rights and interests are the ones protected by the police force.

The table below illustrates, respectively, the principal, the additional accountability mechanism and the expected behavioural outcome in the cases of the autocratic, criminal and autarkic police forces. $^{54}$

\begin{tabular}{|c|c|c|c|c|}
\hline$\frac{\text { IDEAL }}{\text { TYPE }}$ & $\frac{\text { Democratic }}{\text { Police }}$ & $\frac{\text { Autocratic }}{\text { Police }}$ & Criminal Police & Autarkic Police \\
\hline Principal & Citizens & $\begin{array}{l}\text { Ruling political } \\
\text { party }\end{array}$ & $\begin{array}{l}\text { Criminal } \\
\text { Organizations }\end{array}$ & Themselves \\
\hline $\begin{array}{l}\text { External } \\
\text { accountability }\end{array}$ & $\begin{array}{l}\text { Accountable to } \\
\text { people outside } \\
\text { their organization } \\
\text { who are } \\
\text { specifically } \\
\text { designated and } \\
\text { empowered to } \\
\text { regulate police } \\
\text { activity }\end{array}$ & $\begin{array}{l}\text { Accountable only } \\
\text { to people inside } \\
\text { their organization }\end{array}$ & $\begin{array}{l}\text { Accountable to } \\
\text { people outside of } \\
\text { their organization, } \\
\text { but nullifying this } \\
\text { accountability by } \\
\text { posing threats to } \\
\text { or bribing those in } \\
\text { charge of } \\
\text { controlling police } \\
\text { activity }\end{array}$ & $\begin{array}{l}\text { Not accountable } \\
\text { to people outside } \\
\text { of their } \\
\text { organization or } \\
\text { accountable to } \\
\text { people who lack } \\
\text { power and } \\
\text { influence to } \\
\text { effectively } \\
\text { regulate police } \\
\text { activity }\end{array}$ \\
\hline $\begin{array}{l}\text { Human } \\
\text { Rights }\end{array}$ & $\begin{array}{l}\text { Protective of } \\
\text { human rights }\end{array}$ & $\begin{array}{l}\text { Violate human } \\
\text { rights for political } \\
\text { motives }\end{array}$ & $\begin{array}{l}\text { Violate human } \\
\text { rights for criminal } \\
\text { motives }\end{array}$ & $\begin{array}{l}\text { Violate human } \\
\text { rights for } \\
\text { ideological } \\
\text { motives }\end{array}$ \\
\hline $\begin{array}{l}\text { Civil and } \\
\text { Political } \\
\text { Rights }\end{array}$ & $\begin{array}{l}\text { Especially } \\
\text { protective of civil } \\
\text { and political } \\
\text { rights required for } \\
\text { participation in a } \\
\text { democratic } \\
\text { system }\end{array}$ & $\begin{array}{l}\text { Violate civil and } \\
\text { political rights to } \\
\text { suppress political } \\
\text { activity that can } \\
\text { be threatening to } \\
\text { the regime }\end{array}$ & $\begin{array}{l}\text { Indifferent to civil } \\
\text { and political } \\
\text { rights required for } \\
\text { participation in a } \\
\text { democratic system }\end{array}$ & $\begin{array}{l}\text { Can either behave } \\
\text { as the autocratic } \\
\text { or as the criminal } \\
\text { police, depending } \\
\text { on the legacy of } \\
\text { the authoritarian } \\
\text { period }\end{array}$ \\
\hline $\begin{array}{l}\text { Mode of } \\
\text { operation }\end{array}$ & $\begin{array}{l}\text { Servicing the } \\
\text { needs of } \\
\text { individual } \\
\text { citizens and } \\
\text { legitimate private } \\
\text { groups }\end{array}$ & $\begin{array}{l}\text { Servicing the } \\
\text { needs of the } \\
\text { political group in } \\
\text { control of } \\
\text { government }\end{array}$ & $\begin{array}{l}\text { Servicing the } \\
\text { needs of private } \\
\text { criminal groups }\end{array}$ & $\begin{array}{l}\text { Servicing its own } \\
\text { needs and } \\
\text { ideologies. }\end{array}$ \\
\hline
\end{tabular}

\footnotetext{
${ }^{54}$ This table is meant to reflect ideal types in Latin America only. A more complete table would need to include predatory policing, which has been acknowledged in the literature as an ideal type that correctly describes policing in Russia. See Note 52 above.
} 
While no force will perfectly correspond to any one ideal type, the Mexican Federal Police is a good example of the Criminal Police, as many of the police officers work for the drug cartels and protect their trafficking routes rather than enforce the law. The Jamaican Constabulary Force (JCF) shares many characteristics of an Autarkic force, since the JCF often operates by its own rules - regularly killing suspects, taking bribes, abandoning prescribed patrol routes to protect business interests - and the government is unable to control them or prevent extra-judicial killings. The Chilean Carabineros are an excellent example of a police force that is moving from Autocratic to Democratic as a result of reforms following the Pinochet dictatorship. ${ }^{55}$ Since many countries have multiple levels of policing, different types of police agencies can occur within one country. Despite these complexities, this typology is useful in identifying types of reforms and assessing their effectiveness, as we will discuss further below.

\section{POLICE REFORM IN LATIN AMERICA}

A significant amount of financial, political and human resources has been invested in police reform in Latin America. Over the past twenty years, reform efforts have been made in Argentina, Mexico, Brazil, Chile, and other countries in the region. ${ }^{56}$ However, most of these past reform efforts have failed to create effective democratic policing. ${ }^{57}$ Failure of institutional reforms often occurs because reforms do not account for the particularities of each country, its

\footnotetext{
${ }^{55}$ For a long time their operations were coordinated by the Ministry of the Interior but were formally under the Ministry of Defence. In early 2011 they were officially moved under the Minister of the Interior and Public Security (no longer the Minister of Defence). They have widespread popular support and have high levels of legitimacy, despite being still very militarized. See Hugo Fruhling, "Police Legitimacy in Chile" in Legitimacy and Criminal Justice: International Perspectives, ed. Tom Tyler (New York: Russell Sage Foundation, 2007), 115.

${ }^{56}$ Niels Uildriks, Policing Insecurity (Lanham: Lexington Books, 2009); Joseph Tulchin and Meg Ruthenburg, Toward a Society Under Law (Washington: Woodrow Wilson Press, 2006); John Mclean et al., "Jamaica Community Based Policing Assessment,” Jamaican Constabulary Force and USAID, 2008.

${ }^{57}$ Trebilcock and Daniels, Rule of Law Reform and Development, 119-124.
} 
historical legacies and the distinct causes of what may look like relatively common problems. ${ }^{58}$

In this regard, our typology may help reformers to understand some of the central and starker differences between countries, and to design strategies that are adapted to each particular context.

In developing this analysis, this paper will focus on Latin American countries that have transitioned from an autocratic to a democratic regime, excluding the cases of uninterrupted democracies such as Colombia and Costa Rica. The lack of an authoritarian past and a period of democratic transition make these two cases rather distinct from the ones analyzes here. Also, we will not discuss reforms that created new police forces from scratch, following armed conflict and humanitarian crises, as was the case of Guatemala, Haiti and El Salvador. Instead, our focus will be those countries that have gone through a democratic transition but did not have a “window of opportunity” to promote all encompassing reforms. ${ }^{59}$

Scholars have suggested that Latin American countries that did not have the option to "start over”, such as Guatemala, Haiti and El Salvador, can learn from each other's reform efforts. ${ }^{60}$ There are, indeed, many commonalities in the region that may be fruitfully explored by reformers. However, this paper will emphasize the differences among these cases, indicating how each country's context often requires a different reform strategy. More specifically, we will argue that there is a certain sequence that reformers should follow in order to increase the

\footnotetext{
${ }^{58}$ For a more detailed articulation of the idea that institutional reforms in developing countries need to be adapted to the context and cannot be based on blue prints, see Michael Trebilcock and Mariana Mota Prado, What Makes Poor Countries Poor? Institutional Determinants of Development (Cheltanham: Edward Elgar, 2011).

${ }^{59}$ For an explanation of the concept of window of opportunity, and how path dependence impose significant obstacles to all encompassing radical reforms, see Mariana Mota Prado and Michael Trebilcock, "Path Dependence, Development, and the Dynamics of Institutional Reform,” University of Toronto Law Journal 59, (2009).

${ }^{60}$ Heather H. Ward, Police Reform in Latin America: Brazil, Argentina and Chile, in Toward a Society under Law: Citizens and their Police in Latin America, ed. Joseph S. Tulchin and Meg Ruthenburg (Washington: Woodrow Wilson Press Centre, 2006).
} 
changes of success of police reform. ${ }^{61}$ More specifically, reformers should first guarantee that a specific group is not controlling the police force and using it for its own benefits (the principalagent problem). Second, reformers should promote accountability, starting with the most basic mechanisms of accountability, moving to more complex ones only when the basic ones are in place. Third, in certain countries, reformers may need to bypass existing institutions, including the police force, to promote effective reforms. We explore each of these in turn.

\section{a. Independence: Dealing with the Principal-Agent Problem}

The ideal types of autarkic, criminal or autocratic police force help reformers identify the different reasons why police forces are deviating from the democratic criteria and, therefore, should help them design the most desirable strategies to effectively promote democratic policing in each of these particular cases. We start our analysis with the cases in which a specific group has control over the police force and uses it as an instrument to protect its interests. This is the case of autocratic and criminal policing.

In such cases, reformers will need to start reforms by dealing with the principal-agent problem. Internal and external reforms, such as recruitment, training, and punishment for corruption and human rights abuses, are unlikely to be effective, if the principal-agent problem is not dealt with first. Consider, for example, the case of criminal police. Where drug cartels are controlling the police force, any attempts to establish independent ombudsmen or civilian oversight, or to invoke the courts to prosecute corrupt police officers is met with fierce and sometimes violent resistance from the police and the cartels, which have strong incentives to

\footnotetext{
${ }^{61}$ On the importance of sequencing, and for an argument against all encompassing reforms, see Prado and Trebilcock, “Path Dependence, Development, and the Dynamics of Institutional Reform.”
} 
protect their financial interests. Attempts to reform the police in Mexico City in the 1990s suffered from these problems. ${ }^{62}$

Dealing with the principal-agent problem does not necessarily mean effectively moving from a criminal police (where drug gangs are the principals) to democratic policing (where the citizens are the principals). As we will discuss in the next section, establishing citizens as the principals may be one of the last (if not the very last) move in a well-designed sequencing of reforms. Instead, dealing with the principal-agent problem in this case means eliminating the existing principal, so as to at least open up the possibility of contemplating some of the other reforms that could and should ensue.

In this regard, it is necessary to distinguish between control and accountability of police forces. ${ }^{63}$ In the cases of the criminal and the autocratic police force, the principal is the institution that has control over the police force, i.e. it can dictate what a police force can and cannot do, and can effectively use the police force to protect its own interests. Accountability, in contrast, is a system to effectively enforce rules and norms, which is normally backed-up by an effective system of rewards and sanctions. Control and accountability often undermine each other. Indeed, securing the independence of the police is widely acknowledged in the literature as an important step in creating democratic policing. ${ }^{64}$ We argue that eliminating control and securing independence should be the primary concern in cases in which the group that controls the police force (the principal) is likely to undermine attempts to establish effective mechanism of

\footnotetext{
${ }^{62}$ Uildriks, "Policing Insecurity and Police Reform in Mexico City."

${ }^{63}$ Philip Stenning, "The idea of the Political 'Independence' of the Police: International Interpretations and Experiences," in Police and Government Relations: Who's Calling the Shots?, ed. Margaret E. Beare and Tonita Murray (Toronto: University of Toronto Press, 2007).

${ }^{64}$ For a brief overview of the literature on police independence, see Trebilcock and Daniels, Rule of Law Reform and Development, 112-115.
} 
accountability. Indeed, attempts to establish accountability in such cases are likely to fail if the principal-agent problem is not tackled first.

In the specific case of the criminal police, for instance, attempts to make officers comply with the rule of law are likely to be undermined by the corrupting influence of the drug gangs and/or other criminal groups. ${ }^{65}$ The control of the police force by criminal groups creates strong incentives for police officers to act according to criminal interests, not according to the rule of law. Indeed, Sabet makes the point that an upstanding police officer is just as vulnerable to threats of physical harm from the drug cartels as a corrupt officer. When presented with the choice of taking a bribe or receiving a credible death threat from the cartels, even a professional, well-trained officer has a strong incentive to break the law. ${ }^{66}$ In such cases, where officers are coerced by the principal into breaking the law, dealing with the principal-agent problem becomes key. Thus, in the cases of the criminal police, reforms need first to eliminate the control of criminal groups over the police force.

In such cases, it is very likely that external reforms to eliminate the old principal, such as military action against drug gangs, ${ }^{67}$ will bolster attempts at establishing a democratic police force. A clear example of reforms in the city of Rio de Janeiro, Brazil (supported by the state and federal governments) was the installation of Unidades de Polícia Pacificadora, UPPs

\footnotetext{
${ }^{65}$ An example is from Rio de Janeiro is judge Patrícia Acioli, who was recently murdered in what was widely believed to be retaliation for her tough stance against corruption and police involvement in drug gangs, see Amnesty International,"Killing of Brazilian judge exposes police corruption,” Amnesty International, August 16, 2011, accessed October 28, 2011, http://www.amnesty.org/en/news-and-updates/police-suspected-armed-ambush-killedbrazilian-judge-2011-08-16.

${ }^{66}$ Daniel Sabet, "Police Reform in Mexico: Advances and Persistent Obstacles.” In Shared Responsibility, ed. Eric L. Olson, Robert A. Donnelly, and David A. Shirk (Washington: Mexico Institute, 2010), 268.

${ }^{67}$ Countries such as Brazil, Colombia, and Mexico have to dismantle criminal organizations by capturing, imprisoning and killing drug lords and criminal leaders, and by using military occupation of areas controlled by drug trafficking, see The Economist, “Shifting Sands: Mexico's changing drug war,” The Economist, November 26, 2011, accessed February 15, 2012, http://www.economist.com/node/21540289; The Economist, "Conquering Complexo do Alemão,” The Economist, December 2, 2010, accessed March 2, 2012, http://www.economist.com/node/17627963; The Economist "Drugs, war and democracy: A survey of Colombia," The Economist, April 19, 2001, accessed March 2, 2012, http://www.economist.com/node/576197.
} 
(Pacification Police Units). Using new recruits, financial incentives, and different training (police as public officers serving the community, instead of coercion agents), these new units occupy regions formerly dominated by drug dealing organized networks, after these have been expelled from the territory by a highly-trained special unit (BOPE) or in some cases by the army. ${ }^{68}$ Numerous aspects of such reforms contributed to its success, as we discuss in section c infra, but it is important to note that they were preceded by an attempt to remove the older principal (criminal groups).

The problem is that eliminating the criminal principal is an exceedingly difficult process, and often has been associated with major civilian casualties, and raised a number of concerns with human rights violations. ${ }^{69}$ In Brazil, UPPs have tried to avoid violent confrontation between police officers and criminals by announcing in advance the day of military occupation of a certain region (known as favelas). This allows criminals to flee before the police force or the army arrives. However, this strategy has been criticized for allowing criminal groups to simply relocate to other areas. ${ }^{70}$ Along the same lines, such crime elimination and prevention policies may have negative or positive impacts in attempts to establish successful police reforms across national borders. For instance, the destruction of drug cartels in one country may simply lead to the rise of cartels in another. For instance, the military crackdown on the Colombian drug cartels

\footnotetext{
${ }^{68}$ Stephanie Gimenez Stahlberg, "The Pacification of Favelas in Rio de Janeiro: Why the Program is Working and What are the Lessons for Other Countries”, Paper presented at the Conference Violence, Drugs and Governance: Mexican Security in Comparative Perspective, Oganized by CDDRL, CISAC, FSI Stanford, Stanford, October 3-4, 2011, 8-9. Available at http://iis-db.stanford.edu/evnts/6716/Stahlberg,_Stephanie__Pacification_of_Favelas_in_Rio_de_Janeiro_(Work_in_Progress).pdf.

${ }^{69}$ The Economist, “Taking on the gangs," The Economist, August 27, 2011, accessed August 9, 2011, http://www.economist.com/node/21526903; Anne-Marie O’Connor and William Booth, "Torture surges in Mexico’s drug war, rights group says,” The Washington Post, November 9, 2011, accessed March 18, 2012, http://www.washingtonpost.com/world/americas/torture-surges-in-mexicos-drug-war-rights-groupsays/2011/11/09/gIQAphSI6M_story.html.

${ }^{70}$ Stahlberg, "The Pacification of Favelas in Rio de Janeiro: Why the Program is Working and What are the Lessons for Other Countries," 9.
} 
reduced crime in Colombia, but contributed to increased violence in Mexico. ${ }^{71}$ As Mexico attempted its own military crackdown on its cartels in the last few years, drug activity and violence spread to other Central American countries. ${ }^{72}$ As an alternative, Latin American political leaders and public intellectuals have suggested that drug decriminalization may be the most effective strategy to tackle this problem in Latin American. ${ }^{73}$ However, this proposal still face significant political resistance in Latin America and around the world. ${ }^{74}$

Because these policies are not police reforms per ser, but general crime strategies to reduce crime, they are beyond the scope of this paper. Nevertheless, it is important to emphasize that, depending on how they are conducted, such military interventions may be taken as examples of the effectiveness of mano dura policies, reducing popular and police support for democratic reforms in the future. Thus, these tactics create the risk that after the removal of the old principal, there will be support for reforms that make the police authoritarian or autarkic, instead of democratic.

\section{b. Accountability: Chosing the Right Sequence}

Democratic policing, as an ideal type, has the citizens as the principals. In contrast, the autocratic police force is controlled by the ruling party, the criminal police by criminal groups,

\footnotetext{
${ }^{71}$ Davis, "Undermining the Rule of Law."

${ }^{72}$ Rory Carroll, "Guatemala becomes killing field as drug wars spread through Central America," The Guardian, June 28, 2011, accessed March 18, 2012, http://www.guardian.co.uk/world/2011/jun/28/guatemala-town-mexiconarco-wars.

${ }^{73}$ Los Angeles Times, Editorial, “Legalize drugs? It's a valid discussion for U.S., Mexico and others”, April 15, 2012 (indicating that the Presidents of Colombia, Guatemala, and Mexico have proposed decriminalization as an alternative to the war on drugs in the Summit of the Americas). See also, The Latin American Commission on Drugs and Democracy, Drugs and Democracy: toward a paradigm shift (2009) (Advocating for the decriminalization of drug use. The report is endorsed by former presidents Fernando Henrique Cardoso of Brazil, César Gaviria of Colombia and Ernesto Zedillo of Mexico and composed of 17 independent personalities). Available at www.drogasedemocracia.org/Arquivos/declaracao_ingles_site.pdf.

${ }^{74}$ The Economist, "Burn-out and battle fatigue: As violence soars, so do voices of dissent against drug prohibition" Mar 17th 2012.
} 
and the autarkic police by nobody. In these three cases of non-democratic policing, ultimately reformers should aspire to establish the citizens as principal of the police force. The question is whether establishing citizens as principals should be the central concern in all reform efforts. The answer is no.

While the principal-agent problem may be the central issue to be addressed in the case of criminal police forces, efforts to remove the old principal (described in section a supra) should not be immediately followed by efforts to establish the citizens as the new principals. The main reason for this is path dependence. Path dependence theory helps us understand the obstacles to institutional reforms, by providing important concepts such as self-reinforcing mechanisms and switching costs. ${ }^{75}$ It explains, for instance, how actors operating in the current system are likely to resist reforms that impose significant transitional costs for them to adapt to the new system (switching costs). Also, path dependence illustrates how social norms can create an entrenched institutional culture that sets up a behavioural pattern that is hard to change (self-reinforcing mechanisms). These concepts suggests that radical departures from the status quo are likely to face significant resistance, specially within the institution being reformed.

This is the reason why a country that has secured at least autarkic policing (i.e. the police force is not controlled by criminal groups), should not necessarily attempt to establish all at once all the pre-requisites for democratic policing, as described earlier. Most importantly, establishing citizens as principals may be one of the most radical departures from the status quo among such reforms, and is likely to face strong resistance. Therefore, establishing citizens as principals should become more of a concern the closer an autarkic police force is to democratic policing. In many countries, however, other concerns should be addressed before reformers turn their minds

\footnotetext{
75 Prado and Trebilcock, “Path Dependence, Development, and the Dynamics of Institutional Reform.”
} 
to the principal-agent problem. In other words, in normal times, reformers are more likely to succeed if they progressively implement reforms that move an autarkic police force closer to the democratic criteria.

A certain police force may not have any of the features that define democratic policing or it may have them all, but in most of the cases in Latin America police forces are somewhere in between. The Chilean police force, for instance, can be described as a force that has very effective mechanisms of internal accountability, as exemplified by the low levels of corruption and lower levels of police abuse in comparison to other Latin American countries. ${ }^{76}$ However, the Carabineros are still very militarized and lack external accountability. Moreover, despite recent efforts to promote changes in this regard, they have resisted any type of civilian oversight and reforms that create greater proximity between police officers and communities. ${ }^{77}$ Thus, the Chilean police force cannot be considered a clear example of democratic policing, but it is closer to the ideal type than other police forces in the region.

One central distinction that can be made, for instance, is that in Chile officers seems to abide by laws and orders coming from officers in the chain of command. In contrast, in many Latin American countries the police force does not even abide by the basic rules of the system. The police, frustrated by dysfunctional prosecutorial, court, and correctional systems that they believe hamper their efforts to address the crime problem, take the law into their own hands often with the support of many members of the public who believe in a rights/security dichotomy. Attempts to implement internal reforms fail because they are often ignored by the police agency. The police can be assigned to work with the community and establish consultative processes, but they do not take these responsibilities seriously. Argentina is a good example. In

\footnotetext{
${ }^{76}$ See notes 49 and 51 above.

${ }^{77}$ Fruhling, "Police Legitimacy in Chile."
} 
Argentina, the Buenos Aires provincial police are autarkic, as they frequently act on their own authority and cannot be controlled by the government. ${ }^{78}$ This is a case of autarkic police that is further removed from the democratic policing than the Chilean case. As the Chilean case suggests, the police force does not need to be effectively controlled by the citizens to be accountable to the law. Thus, in many cases, one can focus on some more basic issues - such as guaranteeing minimum respect for basic human rights and reducing the levels of corruption before one tries to establish a new principal.

In sum, the task of bringing Latin American police forces closer to the democratic criteria requires one to start by identifying the ways in which a police force deviates from these criteria. In other words, not only the criminal police requires a different reform strategy if compared to the autarkic police force, but also autarkic police forces may deviate more or less from the democratic criteria, requiring different reform strategies. To succeed, reformers need to be sensitive to the particular problems in each country, designing a sequence of reforms that will take these distinct starting points into consideration and gradually bring the police force closer to the democratic criteria.

This is not to suggest that the sequencing of reforms is an entirely technical process. On the contrary, there is an important political dimension in this process that is relevant, especially in the case of autarkic police forces. On the one hand, autarkic police forces are likely to resist externally imposed reforms. On the other hand, if left alone, these forces may never initiate reforms or may promote them internally at a very slow pace and not necessarily favouring what

\footnotetext{
${ }^{78}$ Mark Ungar, "Police Reform in Argentina: Public Security versus Human Rights” in Policing Insecurity, ed. Niels Uildriks, (Lanham: Lexington Books, 2009), 180. See also Matías Dewey, "Fragile states, robust structures: Illegal Police Protection in Buenos Aires”, GIGA Working Paper No. 169. Hamburg: German Institute of Global and Area Studies, Institute of Latin American Studies, June 2011. Available at http://www.gigahamburg.de/dl/download.php?d=/content/publikationen/pdf/wp169_dewey.pdf
} 
citizens would prefer. This creates a dilemma for reformers: should they risk externally imposed reforms that are likely to be strongly resisted, or should they wait for internal initiatives, that may never come to fruition, or may be so isolated that they will not promote systemic changes?

This dilemma is illustrated by the contrasting cases of Argentina and Brazil. Attempts to implement Community-based Policing (CBP) in the Argentinean province of Mendoza shows an externally imposed reform that did not attract internal support and faced strong resistance from police officers. ${ }^{79}$ Conversely, one of the earliest - and relatively successful CBP experiments in the state of Rio de Janeiro were internally initiated reforms. ${ }^{80}$ However, this successful experience covered a small area of the city - a low-income neighborhood known as favela - and was never translated into systemic change. Indeed, colleagues often ostracized the officers working on the project. ${ }^{81}$ Chile may be an example in which there is some combination between external and internal support for reforms, but this means that only after two decades after the end of the military dictatorship, reformers have started to slowly increase external accountability of the Carabineros and have also tried some timid measures to create closer ties between the police officers and the community. ${ }^{82}$

In addition to internal support for reforms, the external support also needs to be robust and stable. The difficulties in aligning the interests of federal, state and local governments in a federalist country like Brazil, Argentina and Mexico have imposed significant obstacles to police

\footnotetext{
${ }^{79}$ Ungar, “Police Reform in Argentina: Public Security versus Human Rights,” 184-186.

${ }^{80}$ Graziella Moraes D. Da Silva and Ignacio Cano, "Between Damage Reduction and Community Policing: The Case of Pavão-Pavãozinho-Cantagalo in Rio de Janeiro’s Favelas,” in Legitimacy and Criminal Justice, ed.Tom Tyler (New York: Russell Sage Foundation, 2007).

${ }^{81}$ Sergio Guimarães Ferreira, "Segurança Pública nas Grandes Cidades,” in Brasil: a Nova Agenda Social, ed. E. Bacha and S. Schwartzman (Rio de Janeiro: Editora LTC, 2011), 298-299.

${ }^{82}$ Ward, Police Reform in Latin America: Brazil, Argentina and Chile, 189-197 (describing the Plan Cuadrante). Fruhling, "Police Legitimacy in Chile”, 125-127 (describing structural reforms).
} 
reform. ${ }^{83}$ Similarly, lack of political stability may quickly change external support for reforms, causing projects to collapse. An example is the failed attempt to reform the police in the province of Buenos Aires. In response to rising crime and corruption in 1996, the provincial government passed strong reforms including firing over 5,000 police officers, promoting Community Based Policing via Neighbourhood Security Forums, and establishing new safeguards for privacy and individual liberties. ${ }^{84}$ These all-encompassing reforms resulted in strong internal ${ }^{85}$ and external resistance, ${ }^{86}$ as politicians and the members of the police force aligned to strongly oppose these measures and dismantle reform efforts. The entire project collapsed.

The idea that reforms to implement accountability mechanisms can and should be sequenced raises an important question about the end point of the reforms. As indicated earlier, the final step in establishing democratic policing is to guarantee that citizens become the principal of the police force. This is ensured through layers of accountability mechanisms that will ultimately allow all citizens to control the force, thereby not allowing any particular citizen or group of citizens to use the police force for its own benefit. In other words, democratic policing mergers the concepts of control and accountability, as articulated by Maravall and Przeworski:

Rule of law emerges when self-interested rulers willingly restrain themselves and make their behaviour predictable in order to obtain sustained cooperation of well-organized groups commanding valuable resources. In exchange for such cooperation, rulers will protect the interests of these groups by legal means. ${ }^{87}$

\footnotetext{
${ }^{83}$ Pereira, "Public Security, Private Interests, and Police Reform in Brazil.” Kent Eaton, “Paradoxes of Police Reform: Federalism, Parties, and Civil Society in Argentina's Public Security Crisis”, Latin American Research Review 43(3) (2008), 5-32.

${ }^{84}$ Ungar, "Police Reform in Argentina: Public Security versus Human Rights", 180-181.

${ }^{85}$ Ward, Police Reform in Latin America: Brazil, Argentina and Chile, 189-197.

${ }^{86}$ Fruhling, "Police Legitimacy in Chile”, 127-8 (contrasting Chile and Argentina). See also Eduardo Estevez, "Public Security and Police Reform in the Province of Buenos Aires: Balancing Preventive and Investigative Police", in Police Behavior: A Reform Approach, ed. G. Radha Kalyani (Amicus Books - Icfai University Press, 2008), 150-190.

${ }^{87}$ Jose Maria Maravall and Adam Przeworski, "Introduction,” in Democracy and the Rule of Law, ed. Jose Maria Maravall and Adam Przeworski (Cambridge University Press, 2003), 2-4.
} 
More to the point, as Holmes states:

Why do people with guns obey people without guns? (...) Societies may proximate the rule of law if they consist of a larger number of power-wielding groups, comprising a majority of the population, and if none of them become so strong as to be able thoroughly to dominate the other. (...) Formulated differently, the balancing of many partialities is the closest we can come to impartiality. ${ }^{88}$

These quotes explain how the idea of control (by citizens in a democratic polity) and accountability (to the law) are intrinsically connected in the case of democratic policing. The effective control of the police force by will be connected with accountability to the law, which is connected to accountability to people outside the organization. The more accountability, the more control there is, because all members of the community are interested in ensuring that no other group is receiving some kind of privilege or benefit to which they are not entitled.

If the ideas of control and accountability are so interconnected, why not advocate for reforms that promote both at the same time? Our proposal seeks to avoid recommending allencompassing reforms because they are riskier and reformers are likely to face significant obstacles to their implementation. Instead, using the typology presented in the part two, we propose a sequence of reforms that are adapted to the different problems faced by different countries. The assumption is that reformers should establish a list of priorities (as opposed to pursuing every single aspect of democratic policing at the same time) and define the optimal sequencing of reforms according to the specific priorities of each country. In designing the sequencing of reforms, reformers should not resort to formulas or blueprints. Different initiatives are likely to work in different contexts.

\footnotetext{
${ }^{88}$ Stephen Holmes, "Lineages of the rule of law” in Democracy and the Rule of Law, ed. Jose Maria Maravall and Adam Przeworski (Cambridge University Press, 2003).
} 


\section{c. Bypassing Dysfunctional Institutions}

Increasing accountability of autarkic police forces requires a network of rule of law institutions that will oversee police activity and effectively use a system of punishment and rewards when necessary. ${ }^{89}$ The challenge for reformers is that some (or all) of these institutions may not be functional, and therefore any attempt to increase accountability of the police force becomes dependent on further rule of law reforms, such as the prosecutorial agency and the courts. This is a challenge that cannot be taken lightly. Rule of law reforms are complex - many fail and even those that succeed take an extended period time to become fully functional. ${ }^{90}$ An example of the complexities involved in such reforms is prosecution and sanctioning of police abuse in Latin America. In a detailed study of five state and provincial jurisdictions in Argentina, Brazil and Uruguay, Daniel Brinks shows that judicial responses to police abuse are dependent on many more variables (such as intrinsic biases in the system and informational and normative failures) than simply an investigative system to collect the necessary information for prosecution to take place, an effective and impartial prosecutorial office, and an independent judiciary. ${ }^{91}$

Thus, to effectively deal with such problems, reformers need to look at the entire system, including victims' access to legal aid, instead of looking at one institution in the system, the police. ${ }^{92}$ In this context, there are important reforms of these other institutions that may help

\footnotetext{
${ }^{89}$ Trebilcock and Daniels, Rule of Law Reform and Development, 107-144. See also, Daniel M. Brinks, The Judicial Response to Police Killings in Latin America (Cambridge University Press, 2008), 247 (on the importance of these institutions in the case of police killings).

${ }^{90}$ Pinheiro, "Governo Democrático, violência e Estado (ou não) de direito”; Pinheiro, "The Paradox of Democracy in Brazil”; Sabet, "Police Reform in Mexico"; Sandro et al., "Monitorando a Polícia”; Michael Trebilcock and M. Prado, What Makes Poor Countries Poor? Institutional Determinants of Development; Trebilcock and Daniels, Rule of Law Reform and Development; Tamanaha, On the Rule of Law: History, Politics, Theory; Carothers, "The Rule of Law Revival”; Erik Jensen, ed., Beyond Common Knowledge: Empirical Approaches to the Rule of Law (Stanford: Stanford University Press, 2003), especially Thomas Heller, Ch. 11 "An Immodest Postscript”; Bryant Garth and Yves Dezelay, "Introduction" in Global Prescriptions: The Production, Exportation and Importation of a New Legal Orthodoxy, ed. Bryant Garth and Yves Dezelay (Ann Arbor: University of Michigan Press, 2002).

${ }_{91}$ Daniel Brinks, The Judicial Response to Police Killings in Latin America (Cambridge University Press, 2008).

${ }^{92}$ Ibid. at 247.
} 
improve police behaviour, ${ }^{93}$ but it is not particularly helpful to suggest that Latin American countries need to revamp their rule of law institutions across the board in order to achieve democratic policing. Without dismissing the importance of political stability and functioning rule of law institutions in securing democratic policing, we ask whether there are specific police reforms that could bring these countries closer to democratic policing.

Despite avoiding these institutional complexities, reform attempts focused on police forces have also faced significant obstacles in Latin America due to path dependence. As indicated in the previous section, there is often resistance by the police force to externally imposed reforms. In addition, political support for reforms needs to be strong and continuous, as opposed to being scattered and volatile, as it has been the case in many countries. It is clear, therefore, that successful reforms are more likely to happen in cases where there is simultaneously external (i.e. political) and internal (i.e. within the police force) support for reforms. ${ }^{94}$ However, these cases are very rare.

External support for police reform depends on so many variables that it is hard to say whether and how reformers could be able to foster or generate such support in countries where none exists. For this reason, we will focus on cases where there is strong political support to promote police reform, but most proposals are likely to face significant resistance within the police force. Our claim is that in such cases there is one strategy that seems particularly promising in overcoming internal resistance to reforms: bypassing the existing police force. This reform strategy does not rely on existing institutions. Instead, reformers create or use parallel police forces to perform the same function as the dysfunctional police force institutions, and try

\footnotetext{
${ }^{93}$ For some of these, see Brinks, The Judicial Response to Police Killings in Latin America, 247-260.

94 Trebilcock and Daniels, Rule of Law Reform and Development, 339-340.
} 
to make them perform such functions in a more effective manner. In another paper, Mariana Mota Prado has called this strategy an institutional bypass. ${ }^{95}$

A recent example of an institutional bypass in police reforms is the recent reforms to create Pacifying Police Units (Unidades de Polícia Pacificadora, UPPs) in Rio de Janeiro, Brazil. The project began in December 2007 and is focused on taking back territories controlled by drug dealers and criminal organizations, mostly in low-income neighborhoods with illegal settlements known as favelas. ${ }^{96}$ The project is divided in three stages: occupation, pacification, and the creation of a new police unit (UPP). ${ }^{97}$ The occupation and pacification are done by an elite police force called BOPE (in some cases with the help of the army). While these first two stages can be described as the removal of the old principal (see section a supra), the third stage, the creation of the UPP, can be considered an institutional bypass. A new UPP performs exactly the same functions of the traditional police force, but is staffed by new recruits that go through a different training, receive higher salaries than the traditional police officers, use different uniforms, and adopt more preventive strategies to prevent crimes. ${ }^{98}$ From the beginning, there was strong political and financial support for the reforms by the federal, state and local

\footnotetext{
${ }^{95}$ Mariana Mota Prado, “Institutional Bypass: An Alternative for Development Reform” (April 19, 2011). Available at SSRN: http://ssrn.com/abstract=1815442 or http://dx.doi.org/10.2139/ssrn.1815442.

${ }^{96}$ Ricardo Henrique and Silvia Ramos, "UPPs Sociais: ações sociais para consolidar a pacificação", in Rio a Hora da Virada, eds. André Urani and Fabio Giambiagi (Elsevier, Rio de Janeiro, 2011), 243. See also Clarissa Huguet and Ilona Szabó de Carvalho, "Violence in the Brazilian Favelas and the Role of the Police", New Directions for Youth Development 119 (2008 Fall), 93-109 (providing a history of favelas and showing the concentration and extremely high incidence of police violence against people living in these areas).

${ }^{97}$ Stahlberg, "The Pacification of Favelas in Rio de Janeiro", 8-9. But see Nicole Maria Turcheti e Melo, "Public Policy for the Favelas in Rio de Janeiro: the Problem (in) Framing”, Master Thesis in Development Studies, International Institute of Social Studies, The Hague, The Netherlands (November 2010) (describing also a fourth phase, called "post-occupation").

${ }_{98}^{98}$ For a detailed description see Stahlberg, “The Pacification of Favelas in Rio de Janeiro”, 13-14. See also Sergio Guimarães Ferreira, "Segurança Pública nas Grandes Cidades," in Brasil: a Nova Agenda Social, ed. E. Bacha and S. Schwartzman (Rio de Janeiro: Editora LTC, 2011), 309 (indicating that reformers refer to UPPs as the "new police”).
} 
governments, which happen to have elected leaders from the same coalition. ${ }^{99}$ However, previous attempts to change the traditional police force, including numerous Community-based Policing programs, had met fierce resistance. ${ }^{100}$ The UPPs avoided this problem of internal resistance by keeping the traditional institution (the old police force) in place and creating a parallel institution that performs exactly the same function but has a different organizational structure.

Any institutional bypass is mindful of the fact that path dependence is a significant obstacle to institutional reforms. However, the UPPs are also mindful of such obstacles in two aspects of their institutional design. First, there is concern with sequencing. For instance, UPPs are not trying to establish citizens as principals. ${ }^{101}$ Instead, the State Department of Public Security in Rio de Janeiro refers to UPP as proximity policing, instead of community policing. ${ }^{102}$ While community policing is often characterized by institutionalized mechanisms to ensure that the police will account for and respond to the needs and interests of the community, the proximity policing adopts strategies to create a respectful dynamic between police officers and members of the community without creating institutional mechanisms of control by the community over the police force. The strategies to create proximity in UPPs are mostly training and a system of financial incentives where police officers receive bonus payments if a certain

\footnotetext{
${ }^{99}$ Ibid., 21. The political support was combined with a higher level of autonomy to the Secretary of Public Security. This autonomy reduced the political interference in the design of reforms, blocking undue electoral pressures and the lack of continuity that characterized previous reforms. Ferreira, "Segurança Pública nas Grandes Cidades," 302.

${ }^{100}$ Sérgio Guimarães Ferreira, "Segurança pública no Rio de Janeiro: o caminho das pedras e dos espinhos," in Rio a Hora da Virada, eds. André Urani and Fabio Giambiagi (Elsevier, Rio de Janeiro, 2011), 73-99.

${ }^{101}$ Ignacio Cano et al., Os Donos do Morro: Uma Avaliação Exploratória do Impacto das Unidades de Polícia Pacificadora (UPPs) no Rio de Janeiro (Forum Brasileiro de Segurança Pública and Laboratório de Análise da Violência - UERJ, May 2012), 144-146. See also Abhijit Banerjee, Raghabendra Chattopadhyay, Esther Duflo, Daniel Keniston, and Nina Singh, "Can Institutions be Reformed from Within? Evidence from a Randomized Experiment with the Rajasthan Police”, NBER Working Paper Series - National Bureau of Economic Research 17912 (2012) (showing some of the difficulties of establishing police reforms in India that depend on sustained cooperation of the communities).

${ }^{102}$ Stahlberg, "The Pacification of Favelas in Rio de Janeiro", 9.
} 
region has reduced rates of crime and police abuse. ${ }^{103}$ Second, there is ample room for experimentation and the program is imbued with flexibility, so that it can adapt to different circumstances. ${ }^{104}$

In addition to the UPPs, one could possibly conceive of some efforts to promote Community Based Policing (CBP) as an example of bypass, as they try to promote accountability by bypassing dysfunctional governance structures. CBP is the conventional wisdom on police reform, as advocated by USAID, the World Bank, and much scholarly writing. Although the concept of CBP admits of a wide range of understandings, ${ }^{105}$ one of its goals in North America is to make the police a proactive institution that responds to the needs of their particular communities. This includes building ties with community members through neighborhood councils, structural changes to the police hierarchy to make it less centralized and more responsive to local conditions, and training of officers on how to build positive relationships with citizens. ${ }^{106}$ The expectation is that such reforms will build trust with communities, make the police be able to respond better to the needs of citizens, better protect their rights, and better respect the rule of law - thereby making them more effective at fighting and preventing crime. In sum, CBP in North America could be described as an effort to establish citizens as principals; the very last step in creating democratic policing according to the sequencing proposed in this paper.

\footnotetext{
${ }^{103}$ Stahlberg, “The Pacification of Favelas in Rio de Janeiro”, 13-14, 27.

${ }^{104}$ Ibid., 29.

${ }^{105}$ CBP encompasses a diverse collection of policies including decentralized authority, a focus on investigative work and preventative measures over reactive policies, and involving communities in the policing process. See Fruhling, Hugo, "A Realistic Look at Latin American community policing programs,” Policing and Society 22, no. 1 (2012): 78; Diane Davis, "Community policing: Variations on the Western model in the developing world," Police Practice and Research 4, no. 3 (2003): 285-286.

${ }^{106}$ John Mclean et al., "Jamaica - Community Based Policing Assessment," 26-29; Paulo de Mesquita Neto, "Paths toward Police and Judicial Reform in Latin America," in Toward a Society under Law: Citizens and their Police in Latin America, ed. Joseph S. Tulchin and Meg Ruthenburg (Washington: Woodrow Wilson Press Centre, 2006), 164.
} 
In the Latin American context CBP should be conceived differently. It should not be a reform to establish citizens as principals. Instead, it is more likely to be successful as a reform to establish the community as an effective oversight mechanism that will make police accountable to the law. Similarly to UPPs, small-scale CBP pilot projects, focusing on a particular neighborhood, can be an important tool for countries that suffer from significant failures in accountability mechanisms at the national, state/provincial or municipal level. Politically or institutionally broad reforms to make these mechanisms effective are complicated and likely to be strongly resisted. Establishing such mechanisms at a lower level, instead, can be a useful approach to reform in the interim as their narrow political scope makes them low-risk projects that require less political capital and investment than comprehensive reforms. Another benefit is that CBPs are small pilot projects that minimize the negative impacts of failed attempts. The Grants Pen project, while a failure in Jamaica, is a good example of minimizing the fallout from experimentation. Since the efforts to implement CBP in $2002^{107}$ were confined to one neighborhood, the lack of success did not deter the government from undertaking another CBP experiment in Flakers Bay in 2006 that proved more successful. ${ }^{108}$ Thus, CBPs are an opportunity to create accountability mechanisms for a single police station that is not under the control of drug gangs.

While very promising in theory, CBP projects do not always work well in practice. CBP has been successfully implemented in developed, democratic countries such as the United States, ${ }^{109}$ but attempts to adopt these methods in Latin America have met with mixed results. ${ }^{110}$

\footnotetext{
${ }^{107}$ Mclean et al., “Jamaica - Community Based Policing Assessment,” 2.

${ }^{108}$ Eric Beinhart, "Jamaica Fights Gangs and Violence Island-wide,” USAID FrontLines, 2010, 6.

109 Fruhling, "The Impact of Community Policing and Police Reform," 46; Fruhling, "A Realistic Look at Latin American community policing programs," 78.

110 Fruhling, "The Impact of Community Policing and Police Reform," 45-46; Davis, "Community policing: Variations on the Western model in the developing world."
} 
Our hypothesis in the Latin American context is that many CBP projects fail, in part, because of the broader institutional environment. While CBPs in North America and Europe have selfreinforcing accountability mechanisms at the higher levels, CBPs in Latin America seek to make lower level mechanisms of accountability effective without reinforcements at the higher level. This makes the task significantly more challenging, but it also makes it significantly more relevant as the CBP is likely to be one of the few, if not the only effective accountability mechanism in many cases.

Given the lack of mechanisms of accountability at higher levels, one risk that CBPs face in Latin America is the risk of capture. Indeed, a common CBP reform is to increase engagement between the police and a particular neighborhood by creating a forum where police and community can interact. ${ }^{111}$ These forums can take the form of neighborhood committees, community panels, or local security fronts. ${ }^{112}$ However, there are many obstacles to these forums becoming effective mechanisms of civilian oversight. In general, the communities in which people have the time to volunteer on committees and boards tend to be those that need CBP the least. ${ }^{113}$ In other cases, community panels are dominated by a small group of people that is not representative of the interests of the entire community. This unrepresentative minority often pursues pet projects that yield little benefit in terms of social safety. In other words, a small group starts to control the local police force and use it for its own benefits. Examples abound. In

\footnotetext{
${ }^{111}$ Ungar, "Police Reform in Argentina: Public Security versus Human Rights,” 181; Markus-Michael Muller, "Community Policing in Latin America: Lessons from Mexico City," European Review of Latin American and Caribbean Studies 88 (2010): 26; Llorrente, María Victoria Llorrente, “Demilitarization in a War Zone,” in Public Security and Police Reform in the Americas, ed. John Bailey and Lucía Dammert (Pittsburgh: University of Pittsburgh Press, 2006).

112 Llorrente "Demilitarization in a War Zone”; Alberto Fohrig, Julia S. Pomares, and Cecilia Gortari. "Citizen Security Policy in Argentina: The National Crime Prevention Plan,” in Toward a Society Under Law:Citizens and Their Police in Latin America, ed. Joseph S. Tulchin and Meg Ruthenburg (Washington: Woodrow Wilson Center Press, 2006), 246-247.

${ }^{113}$ Christopher E. Stone and Heather H. Ward, “Democratic policing: A framework for action,” Policing and Society 10 , no. 1(2000).
} 
Mexico City, the Policia de Barrio, those who sat on the neighbourhood committees "tended to 'privatize the Policia de Barrio assigned to their neighbourhood and use them for private purposes.”114 In the Grants Pen neighbourhood of Kingston, Jamaica, for example, a pilot project sponsored by USAID failed because local stakeholders paid the police to change their routes and protect business interests.

In these cases, the risk of capture can be reduced by changing the governance structure of community panels and neighborhood boards to increase the plurality of groups represented in these panels or commissions. In Costa Rica, for example, a successful CBP program in the Hatillo neighborhood was overseen by a committee with representatives from "the community at large, churches, sports leagues and health services." ${ }^{115}$ Along the same lines, Fruhling suggests that a mixed commission model with representatives from governmental and non-governmental institutions is more likely to generate desirable outcomes than neighborhood commissions. ${ }^{116}$

As the examples above illustrate, for CBP to effectively operate as a bypass of otherwise ineffective accountability mechanisms within the state, the active and continuous participation of the community in CBP projects is key. ${ }^{117}$ However, even without capture, there may strong resistance inside the police force to community policing. ${ }^{118}$ Indeed, one aspect that is common to different countries is that such reforms, if externally imposed, are less likely to be effective, as

\footnotetext{
${ }^{114}$ Muller, “Community Policing in Latin America: Lessons from Mexico City,” 28.

${ }^{115}$ Randall and Ramirez, "Policing the Police: Formal and Informal Police Oversight Mechanisms in the Americas," 12.

${ }^{116}$ Fruhling, "The Impact of Community Policing and Police Reform.”

${ }^{117}$ Niels Uildriks, "Mexican Police and Reform: A Theoretical Introduction," in Mexico's Unrule of Law, ed. Niels Uildriks (Lanham: Lexington Books, 2010), 26-27; Hugo Fruhling, "The Impact of Community Policing and Police Reform," in Toward a Society under Law: Citizens and their Police in Latin America, ed. Joseph S. Tulchin and Meg Ruthenburg (Washington: Woodrow Wilson Press Centre, 2006).

${ }^{118}$ Anthony Harriott, "Police Transformation and International Cooperation - The Jamaican Experience," in Policing Insecurity: Police Reform, Security, and Human Rights in Latin America, ed. Niels A. Uildriks (Lanham: Lexington Books, 2009); Uildriks, “Mexican Police and Reform: A Theoretical Introduction,” 29.
} 
discussed in the previous section. Creating a new police force, as was the case with Brazil's UPPs, may be an effective strategy in overcoming this resistance.

The Brazilian case of UPPs also illustrates how governmental reforms can be positively reinforced with the support of external groups. In addition to financial support for police reform, a group of business people hired a private consulting firm to map dysfunctional processes and create a modernization plan for the State department in charge of the police force (Secretaria de Segurança Pública), which is a civilian body that was clearly incapable of effectively performing its oversight functions. In addition to business people, a group of scholars contributed ideas and proposals, enriching the dialogue. ${ }^{119}$ Thus, with the help of these external groups, what started as small pilot projects in certain communities is now becoming a broader institutional reform of the police force at the state level. The fact that multiple groups with divergent interests were involved in the reform process probably reduced the risk of one group capturing the police and using it to protect their own interests, as was the case in the Grants Pen project in Jamaica.

Including a wide array of services in addition to public security, such as sanitation and public revitalization, Business Improvement Districts (BIDs) seem to be an example in which a similar structure is at work. ${ }^{120}$ A clear example of BIDs in Latin America is the Projeto Zonas Seguras in Bogota, Colombia, where the involvement of business people provided financing and accountability that contributed to the success of these reforms. ${ }^{121}$ However, BIDs in Guatemala have excluded (formally and informally) lower classes, making the benefit of enhanced security exclusive to a certain portion of the population. ${ }^{122}$ This has been attributed to the fact that such

\footnotetext{
${ }^{119}$ Ferreira, "Segurança Pública nas Grandes Cidades,” 301-302.

${ }^{120}$ Lorlene Hoyt and Devika Gopal-Agge, "The Business Improvement Model: A Balanced Review of Contemporary Debates”, Geography Compass 1, no. 4 (2007); Jerry Mitchell, "Business Improvement Districts and the 'New' Revitalization of Downtown,” Economic Development Quarterly 15, no. 2 (2001).

${ }^{121}$ Ferreira, "Segurança Pública nas Grandes Cidades,” 298-299.

${ }^{122}$ Kevin Lewis O’Neill and Kedron Thomas, ed., Securing the City: Neoliberalism, Space, and Insecurity in Postwar Guatemala (Durham: Duke University Press, 2011), 84-87.
} 
projects have relied on private security forces, which is a different type of bypass than the one discussed here. In the Brazilian experience, the government is the one creating a parallel public institution, instead of bypassing a public institution with a private one. ${ }^{123}$ In any event, such cases may indicate one of the limits of excessive reliance on small, localized pilot projects and some of distributive concerns associated with them. ${ }^{124}$

It is important to clarify that the bypass does not need to be limited to the actual police force and its internal governance structures, as the examples above illustrate. Indeed, reformers can bypass the institution that provides information about police abuse and misconduct to the officials that are able to carry on disciplinary measures. For instance, Daniel Brinks analyzes in detail cases of police abuse in Latin America and concludes: "one of the crucial preconditions for an effective rule of law is the presence of multiple alternative sources of information concerning the conduct of lower level actors in the system, including ordinary citizens”. ${ }^{125}$ In light of the failure of the state to provide such alternative sources of information, in some countries NGOs fill this vacuum, either by conducting independent investigations that will provide the system with more information, or by providing victims with the necessary resources to seek more effective assertion of their legal rights. ${ }^{126}$ The important aspect of these bypasses is the fact that they are seeking to correct imbalances in the system, by providing those who are deprived of power, influence and resources with means to seek justice. This suggests that bypasses internal to police forces can perhaps be complemented by external bypasses that enhance the

\footnotetext{
${ }^{123}$ For the distinction between public-public and public-private bypasses, see Prado, “Institutional Bypass", 34-37.

${ }^{124}$ Jill Simone Gross, "Business Improvement Districts in New York City’s Low-Income and High Income Neighbourhoods,” Economic Development Quarterly 19 (2005). Gross discusses how the size of the BIDs, balance of power among stakeholders, and wealth of communities impact on the outcomes.

${ }^{125}$ Daniel Brinks, The Judicial Response to Police Killings in Latin America: Inequality and the Rule of Law (Cambridge University Press, 2008), 254.

${ }^{126}$ Ibid. at 247.
} 
functionality of other rule of law institutions, therefore enhancing the overall accountability of the police force.

\section{CONCLUSION}

The core problem of policing in Latin America is how to successfully transition to democratic policing, starting by creating a police force that is accountable to the law and culminating with the establishment of citizens as the principals. The line that marks the end of one phase of reforms and the beginning of the next is blurred and hard to define. Moreover, there is no blueprint that can be used as a model for all countries. In this context, the purpose of the paper is not to provide a formula. Instead, our goal is to define where our core institutional concerns should lie, acknowledging that the institutional details that will effectively address these concerns will vary from country to country, and even across different regions within the same country.

Our main argument is that our core institutional concern with police reform should vary from case to case. Latin America's transition to democracy in the 1970s and 80s was the first step in moving away from authoritarian police regimes, where the police was simply an agent of autocratic governments. Democratizing these police agencies means creating a police force that is accountable to the law and it also means removing the old principal (the authoritarian regime), and establishing a new one, the citizenry. However, in this process many Latin American countries have ended up with criminal and autarkic police forces (where criminal groups are the principals or there is no principal) that have varying degrees of accountability to the law. Transforming these into democratic police forces has proven challenging. As we argue in the paper, successful and unsuccessful reform projects can be associated with effective and 
ineffective governance mechanisms, and some successful cases may provide guidelines for future action.

As the Arab Spring continues to unfold in the Middle East, middle-income countries in this region have the potential for a similar transition to democracy. Tunisia, Egypt, and Libya middle-income countries that have had authoritarian police agencies - have already overthrown their authoritarian political regimes. ${ }^{127}$ Ongoing protests in Yemen, Syria, and other Middle Income countries suggest changes may also occur there. ${ }^{128}$ The outcome of the Arab Spring revolutions is highly uncertain, but if a wave of democratization occurs in the region, then the lessons of our paper and of other countries that have gone through democratic transitions ${ }^{129}$ should be considered when attempting to reform the authoritarian police agencies in these countries. Addressing authoritarian legacies and principal-agent problems, taking advantage of windows of opportunity, and selecting the appropriate political and institutional scope of reforms will be crucial if the Middle East is to avoid the pitfalls that have thwarted many reform efforts in Latin America.

\footnotetext{
${ }^{127}$ David D. Kirkpatrick and David E. Sanger, “A Tunisian-Egyptian Link that Shook Arab History,” The New York Times, February 13, 2011; Foreign Policy, "The Dark Corners of Qaddafi's Police State,” Foreign Policy, September 6, 2011, accessed January 12, 2012, http://www.foreignpolicy.com/articles/2011/09/06/the_dark_corners_of_qaddafis_police_state.

${ }^{128}$ The World Bank, "Country and Lending Groups," The World Bank, accessed January 12, 2012, http://data.worldbank.org/about/country-classifications/country-and-lending-groups\#Lower_middle_income.

${ }^{129}$ Gerber \& Mendelson, "Public Experience of Police Violence and Corruption in Contemporary Russia."
} 
Appendix -

[Insert Table Here] 